\title{
GENERIC REALIGNMENTS IN MAXILLARIINAE (ORCHIDACEAE): CORRIGENDA ET ADDENDA
}

\author{
Mario A. Blanco ${ }^{1,2}$, German Carnevali ${ }^{3}$, W. Mark Whitten ${ }^{4}$, Rodrigo B. Singer 5 , \\ Samantha Koheler ${ }^{6}$, Norris H. Williams ${ }^{4}$, Isidro Ojeda ${ }^{7}$, Kurt M. Neubig ${ }^{1}$ \\ \& LORENA ENDARA ${ }^{1}$
}

${ }^{1}$ Department of Botany, University of Florida, 214 Bartram Hall, Gainesville, FL 32611-8526, U.S.A. (mablanco@ufl.edu,kneubig@ufl.edu, lendara@flmnh.ufl.edu)

${ }^{2}$ Jardín Botánico Lankester, Universidad de Costa Rica, Apdo. 1031-7050, Cartago, Costa Rica.

${ }^{3}$ Herbario CICY, Centro de Investigación Científica de Yucatán (CICY), calle 43 No. 130, Col. Chuburná de Hidalgo, 97200 Mérida, Yucatán, México. (carneval@cicy.mx)

${ }^{4}$ Florida Museum of Natural History, University of Florida, P.O. Box 117800, Gainesville, FL 32611-7800, U.S.A. (whitten@flmnh.ufl.edu, orchid@flmnh.ufl.edu)

${ }^{5}$ Departamento de Botânica, Instituto de Biociências, Universidade Federal de Rio Grande do Sul, CEP 91501-970, Porto Alegre, RS, Brazil. (rbsinger1@yahoo.com)

${ }^{6}$ Departamento de Genética, Escola Superior de Agricultura “Luiz de Queiróz”, Universidade de São Paulo, C.P. 83, Piracicaba, SP, Brazil 13400-970. (samantha.koehler@gmail.com)

${ }^{7}$ Center for Plant Research, University of British Columbia, \#302-Macmillan Building, 2357 Main Mall, Vancouver, B.C., Canada V6T 1Z4. (isidro@interchange.ubc.ca)

1) Two new combinations for the basionym Maxillaria bomboizensis Dodson were made in Blanco et al., (2007), one in Camaridium (page 519) and another in Sauvetrea (page 535). The first was accidentally left undeleted after we confirmed the correct placement of this taxon in Sauvetrea, and therefore should be considered a synonym:

Sauvetrea bomboizensis (Dodson) M. A. Blanco, Lankesteriana 7: 535.2007. Camaridium bomboizense (Dodson) M. A. Blanco, Lankesteriana 7: 519. 2007, syn. nov.

2) The wrong year (1964) was given for the basionym Ponera adendrobium Rchb.f. [Ornithidium adendrobium (Rchb.f.) M. A. Blanco \& Ojeda] (page 532). The correct year of publication for Ponera adendrobium is 1865 . The rest of the citation is correct and therefore the transfer is valid (see article 33.4 of the Code; McNeill et al., 2006).

3) The following combinations were not included in the article, and are thus validated here:
Camaridium carinulatum (Rchb.f.) M. A. Blanco, comb. nov.

Basionym: Maxillaria carinulata Rchb.f., Flora 41: 6. 1877.

Ornithidium fasciculatum (C. Schweinf.) M. A. Blanco \& Ojeda, comb. nov.

Basionym: Maxillaria fasciculata C. Schweinf., Bot. Mus. Leafl. 15: 162. 1952.

ACKNOWLEDGEMENTS. We would like to thank Eric Hágsater (AMO) and James D. Ackerman (UPRRP) for calling our attention to errors 1 and 2 respectively.

Literature Cited

Blanco, M.A., G. Carnevali, W. M. Whitten, R. B. Singer, S. Koehler, N. H. Williams, I. Ojeda, K. M. Neubig, L. Endara. 2007. Generic realignments in Maxillariinae (Orchidaceae). Lankesteriana 7: 515-537.

McNeill, J., F. R. Barrie, H. M. Burdet, V. Demoulin, D. L. Hawksworth, K. Marhold, D. H. Nicholson, J. Prado, P. C. Silva, J. E. Skog, W. J. Wiersema, \& N. J. Turland. 2006. International Code of Botanical Nomenclature (Vienna Code). Reg. Veg. 146. 